\title{
Use of Electronic Journals through UGC-Infonet Consortium by the Research Scholars of Sri Venkateswara University, Tirupati A Study
}

\author{
Dr. M.Prasantha Kumari ${ }^{1}$ Dr. S.Lakshmi ${ }^{2}$ \\ ${ }^{1}$ Department of Library and Information Science, Sri Venkateswara University, Tirupati, A.P. \\ ${ }^{2}$ Department of Library and Information Science, Intell Engineering College, Anantapuramu, A.P.
}

\begin{abstract}
The study aimed at the use of E-journals through UGC-INFONET consortium and its impact among the research scholars of Sri Venkateswara University, Tirupati. Structured questionnaire was designed to collect the data. Out of 157 questionnaires 148 filled in questionnaires were received back. The present study demonstrates and elaborates the various aspects of use of UGC-INFONET consortium such as frequency of library visits, purpose of using e journals, awareness about UGC INFONET, place of accessing e journals, type of referred journals, preferred search, search method, preferred form, level of satisfaction of internet facility, opinion on information content in e journals and problems faced by research scholars while accessing $e$ journals through UGC INFONET consortium. And also highlights the suggestions made by the research scholars of Sri Venkateswara University who are the respondents of the study.
\end{abstract}

Keywords: Consortium, Electronic journals, Electronic resources, UGC-INFONET, University library

\section{Introduction}

\section{Introduction}

The process of Information acquiring, storing, organizing, accessing and retrieving has changed due to recent advances in Information and Communication Technology. It has led to the creation and organization of Electronic Information Resources. These Electronic Information Resources include E-journals, E-books, CDROM Databases, Online Databases etc.. Electronic Journals are being used by the academic community in the Universities. They are the main resources especially for the researchers and occupying a significant role in their research. The research scholars need to refer number of journals to write the literature review which is very important in the Social Science Research.

\subsection{Previous studies}

Teachers, research scholars as well as students have conducted significant studies on the present topic UGC INFONET and use of e- journals. They help the researchers who are the authors of the present article, to establish the importance of the topic and provide background information needed to understand the study. The authors tried to establish the study as one link in a chain of research that is developing knowledge in the field. Here the authors present few relevant searches which they have referred to complete the study.

The paper was written to provide an insight into UGC-Infonet Project and bring awareness to the library and information professionals, research scholars, and faculty and post graduate students of library and information science regarding how to access library and information science electronic journals covered under UGC-Infonet project for their academic and research activities. (Vishala, B, 2005). A survey was conducted through a questionnaire circulated among 40 research scholars ( Ph.D and M.phil) and 28 students (MLISC)studying in the DLIS, University of Delhi and the response rate was 94 per cent. The study showed that e-journals performed an increasingly important role in research and the users felt the need for training in the area of managing references in using e-journals (Madhusudhan, 2008). The study focused on the use of the UGC-Infonet Digital Library Consortium Resources by research scholars and faculty members of university of Delhi in History and Political Science. The paper attempted to define the consortium, its objectives, scope, eresources subscribed and the government initiative to provide current information in various disciplines for research and teaching excellence. (Bhatt, 2010). The survey was conducted among 100 research scholars of various departments like history, Political Science, Psychology, Sociology and Economics at the faculty of Arts, Banaras Hindu University, Varanasi. The study found that there was a demand for more e-journal titles although a substantial number of users (61.90\%) are satisfied with the existing model of UGC-Infonet Consortium. The study concluded that comprehensive training on availability and usability would be of great help to the users.(Mukherjee and Prashant Kumar, 2010). The study examined the use of UGC-INFONET consortium by the research scholars of Delhi University, Delhi. It was revealed that most of the research scholars were 
aware about the consortium and the purpose of accessing was they used consortium for research and for keeping update in their subjects. Most of the scholars felt easy to use E-journals rather than printed journals. But the level of satisfaction regarding the facility of internet is low. They were in need of full text articles and they required effective training and orientation course on how to use e-journals effectively.(Ahmad, Basha and Fatima, 2012). The paper focused on the study of usage of e-resources available through UGC-INFONET Digital Library Consortium by University of Pune users. The objective was to find trends in usage of eresources and which e-resources were used to the maximum and the study revealed that usage of e-resources is increasing and more uses were getting awareness of e-resources and using e-databases. The study revealed various patterns of use by the professors and Associate Professors and they got to acquire the guidance and experience for accessing the scholarly journals from the library staff and from the senior faculty members. It was found that lack of training for accessing is an obstacle in proper and full utilization of them. (Baskaran and Kishore Kumar, 2013). The paper focused on the study of usage of e-resources available through UGCINFONET Digital Library Consortium by University of Pune users. The objective was to find trends in usage of e-resources and which e-resources were used to the maximum and the study revealed that usage of e-resources is increasing and more users were getting awareness of e-resources and using e-databases.(Nagesh Lakshman and Neela, 2013).

About UGC-Infonet Digital Library Consortium The UGC-Infonet Digital Library Consortium was formally launched in December, 2003 by Honorable Dr. A P J Abdul Kalam, the then President of India soon after providing the Internet connectivity to the universities in the year 2003 under the UGC-Infonet programme. The Consortium proved to be a recipe to university libraries which have been discontinuing subscription of scholarly journals because of "Serials Crisis". The term "serials crisis" refers to exponential and continuing increase in subscription cost of scholarly journals. The crisis is a result of rise in cost of journals much faster than the rate of inflation, increase in number of journals and the paucity of funds available to the libraries.

The Consortium provides current as well as archival access to more than 4500 core and peer-reviewed journals and nine bibliographic databases from 23 publishers and aggregators in different disciplines. The programme has been implemented in phased manner. In the first phase that began in 2004, access to e-resources was provided to 50 universities who had Internet connectivity under the UGC-Infonet Connectivity programme of the UGC. In the second phase, 50 more universities were added to the programme in the year 2005. So far 120 Universities out of 171 that come under the purview of UGC, have been provided differential access to subscribed e-resources. These e-resources cover almost all subject disciplines including arts, humanities, social sciences, physical sciences, chemical Sciences, life sciences, computer sciences, mathematics, statistics, etc. The programme was wholly funded by the UGC and executed by the INFLIBNET (Information and Library Network) Centre, Ahmedabad.

Information and Library Network (INFLIBNET) Centre is an Autonomous Inter-University Centre (IUC) of University Grants Commission (UGC) involved in creating infrastructure for sharing of library and information resources and services among Academic and Research Institutions. INFLIBNET works collaboratively with Indian university libraries to shape the future of the academic libraries in evolving the information environment.

\subsection{Sri Venkateswara University- Brief profile}

Sri Venkateswara University was started in the year 1955 to serve the information needs of the Students, Researchers and Faculty Members of the SVU College of Arts and Sciences \& SVU College of Engineering and Non-teaching staff. It has a total collection of 3, 69,000 volumes which includes 40,000 bound volumes of journals and nearly 3600 theses and dissertations. It currently subscribes to 425 current Journals of national and international importance.

The library provides services such as lending of books, Reference and Bibliographic Service, Reprographic Service and Inter Library Loan Service. The Novel feature of University Library is the establishment of "Competitive Examinations Cell" in the year 2000 with the main objective of providing reading material for student community preparing for various competitive examinations. The Cell provides books and journals relating to Civil Services, Andhra Pradesh Public Service Commission, TOEFL, GATE, GRE, GMAT, CAT, UGC-NET and other competitive examinations. The library also offers the following web-based information services:

- Digital Library includes Theses and Dissertations submitted to SVU and publications of SVU Faculty.

- HDD: Harvester of Digital Documents, through this service one can access full text of publication available in world wide Open Access digital repositories of Chemistry.

- OAIster. Using OAIster website one can access full-text publication on every conceivable subject

- On-line Journals. One can access Free Internet journals on various subjects. In addition, if the users are on

SVU LAN (Local Area Network) can access UGC-INFONET Journals.

Here the authors present the home page of Sri Venkateswara University Digital Library. 


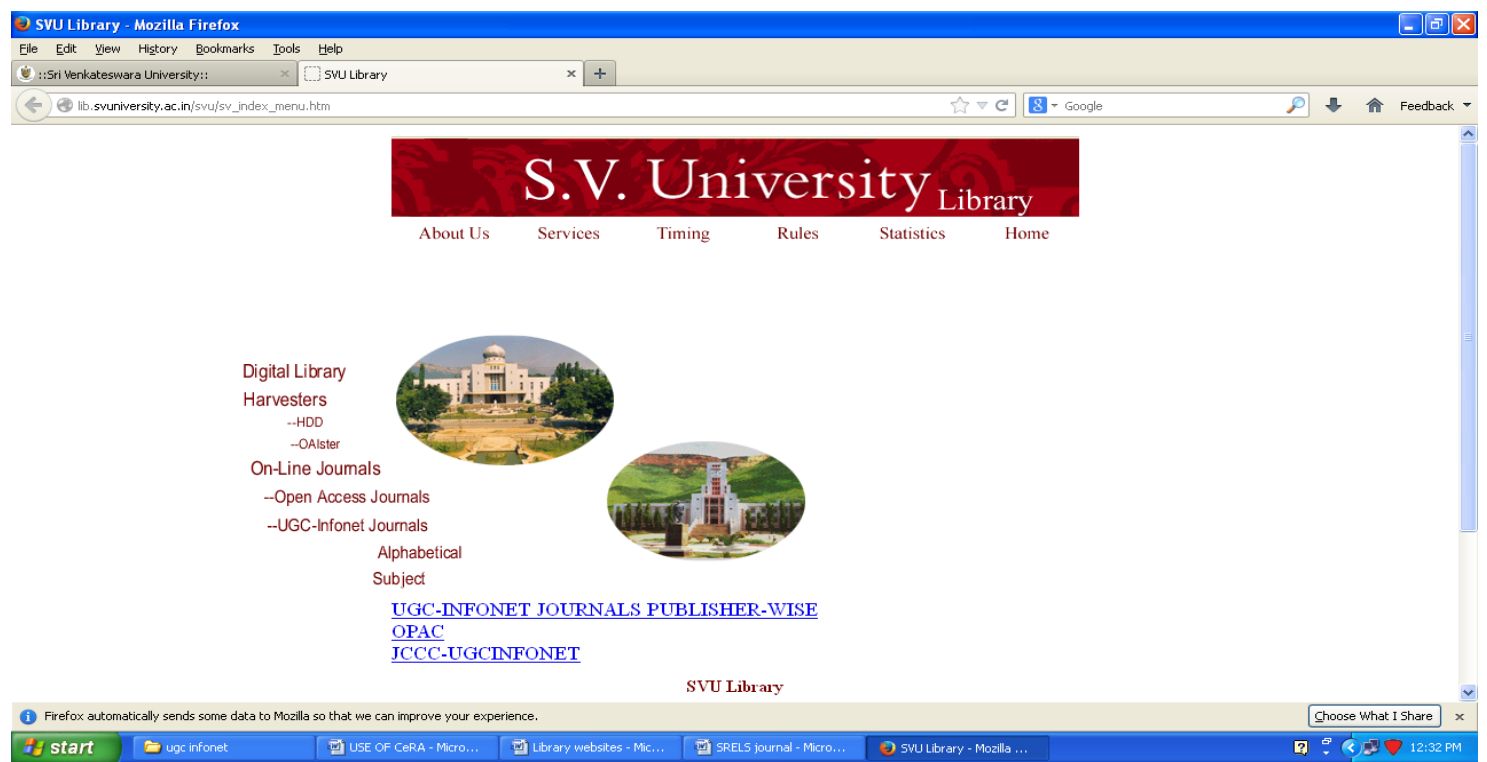

\subsection{Objectives}

1.4.1. To identify the use and impact of UGC-INFONET Consortium on students

1.4.2. To know the purpose of using Consortium

1.4.3. To know the satisfaction of users while using Consortium

1.4.4. To know the problems faced by the students in accessing e-journals through Consortium

1.4.5. To suggest the ways and means for effective use of UGC- INFONET Consortium.

\subsection{Methodology}

Questionnaire method is followed to collect the data from the students. For this, a questionnaire was prepared and distributed to 157 students. Out of 157 users, 148 users have responded. Total response from the users is $94.26 \%$. The collected data is presented in the form of tables and analyzed by using a simple method of calculation.

\subsection{Scope for the study}

The present study focuses on the Use of Electronic Journals through UGC-Infonet Consortium by the research scholars of Sri Venkateswara University, Tirupati: A Study.

\section{Results and discussions}

It is evident from Table.1 that $64(43.24 \%)$ respondents visit library daily. About 42 (28.37\%) respondents visit library once in a week, this is followed by $21(14.18 \%)$ respondents visiting library fortnightly, $13(8.78 \%)$ respondents visiting library once in a month and about $08(5.41 \%)$ respondents visiting the library occasionally. The same data is shown in Fig. 1with a pie diagram.

Table 2 depicts that $148(100 \%)$ respondents are aware of the UGC-Infonet Consortium.

It is evident from table. 3 that $82(55.41 \%)$ of the respondents know the consortium through library staff followed by $32(21.62 \%)$ respondents through friends, 21 (14.18\%) respondents through teachers and about 13 $(8.78 \%)$ respondents know it by themselves. (Shown in Fig.2)

Table 4 shows that 76(51.36\%) respondents were accessing e-journals in their departments whereas $72(48.64 \%)$ respondents were accessing in the library. (as shown in Fig.3)

Table .5 represents that $82(55.41 \%)$ respondents are using e-journals for the purpose of their study/Research whereas $48(32.43 \%)$ are using to publish articles and about $18(12.16 \%)$ respondents are using to update themselves in the subject area. (as shown in Fig.4)

It is evident from table.6 that $92(62.16 \%)$ respondents preferred peer reviewed journals, $38(25.67 \%)$ respondents preferred professional journals and about 18(12.16\%) respondents preferred society publications.Fig. 5 shows this data diagrammatically.

Table .7 depicts that 53(35.81\%) respondents were searching through My Journals, 52(35.13\%) respondents through browse journals, 28(18.91\%) through quick search and about $15(10.13 \%)$ are searching through Advanced Search. (Fig. 6) 
It is clear from Table. 8 that research scholars of Sri Venkateswara.University followed different search methods such as Author search (25.67\%), Title search (29.05\%), Subject search (10.13\%) and key word search (35.13\%). But maximum number of respondents opt keywords like search method. (Fig.7)

From Table. 9 it is understandable that maximum number of $(83.10 \%, 123$ research scholars) respondents gave preference to access full text articles from e-journals and remaining $(16.89 \%, 25$ research scholars) respondents gave preference to access only the abstracts from e-journals. (Fig.8)

Generally the habits of persons are different. In the same way the habits of respondents of present study are also different. From the analysis $69.59 \%$ of research scholars gave preference to save articles in separate folder for further reference, $23.64 \%$ wanted to read articles online directly and only $6.75 \%$ gave preference to take printouts. This is shown in table.10. (Fig.9)

It is very clear that from Table. 11 that $100 \%$ of respondents are opinioned that there was an impact of UGC infonet journals on study/ research. (Fig.10)

Table. 12 says that $66.21 \%$ of research scholars were satisfied with existing internet facility and only $33.78 \%$ were dissatisfied with the same.

Table.13 is regarding respondents' opinion on information content in e-journals when compared to print versions. Maximum number of $(63.51 \%)$ respondents opined that information content in e-journals was better than print versions, $8.10 \%$ of respondents felt that they were same as that of print versions, $2.71 \%$ respondents felt that they were not better than print versions and $25.67 \%$ respondents expressed the opinion i.e. 'not sure'.

Table.14 represents the problems which were faced by research scholars while accessing e-journals through UGC-infonet in S.V. University, Tirupati. The problems they mentioned were lack of availability of personal computers and bandwidth (16.89\% respondents), unfamiliarity with the search methods $(76.35 \%$ respondents), information was not relevant to the subject (4.72\% respondents) and lack of support from the library staff $(2.02 \%$ respondents).

From Table.15 it can be understood that $68.91 \%$ of respondents felt that there was a need for orientation / Training programme to access e-journals through UGC-Intone and remaining (31.09\%)felt that not necessary any orientation or training was not necessary for the same.

$84.46 \%$ of research scholars expressed their feeling about UGC infonet consortium as a boon for them, but $15.54 \%$ answered that it was not a boon.

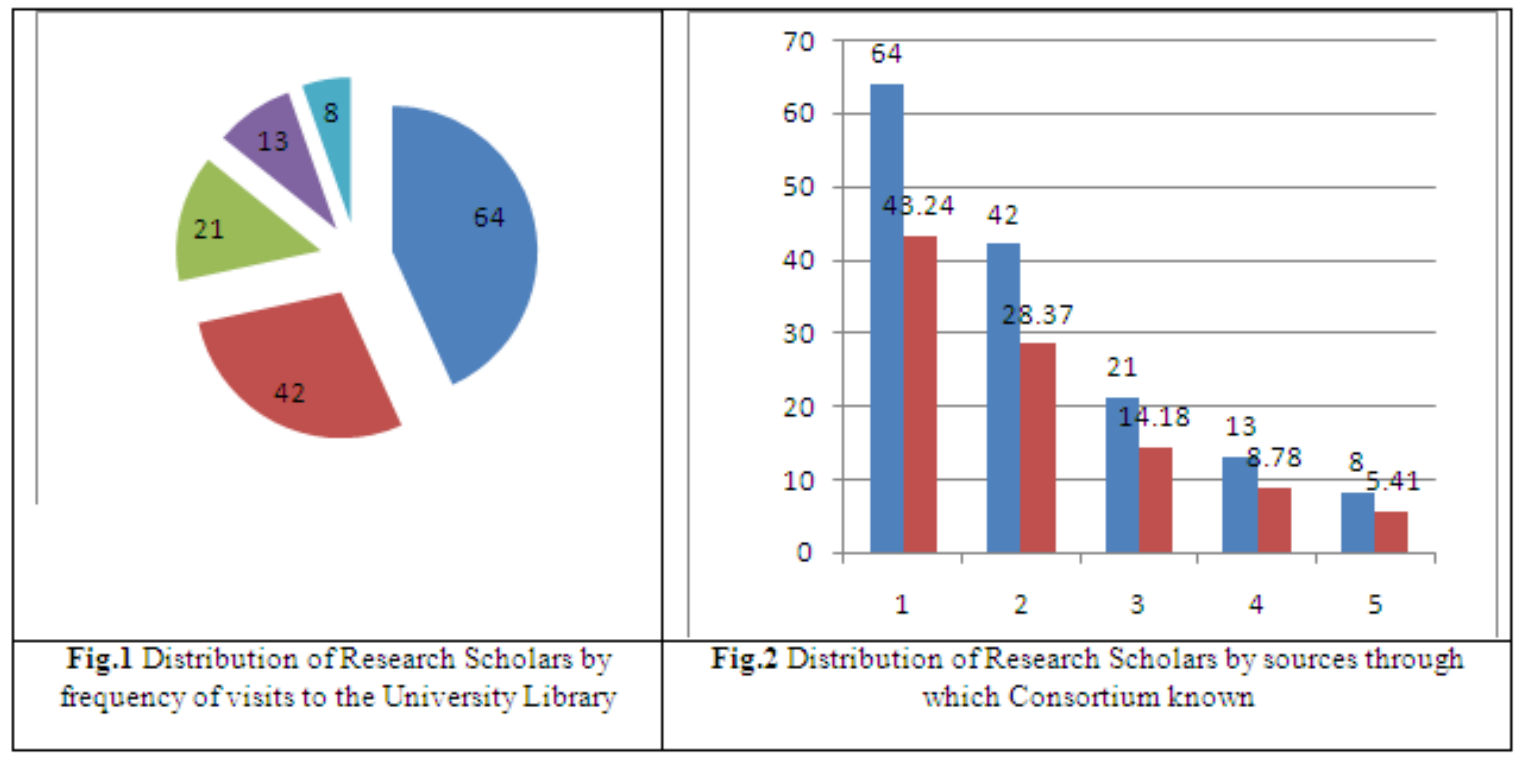




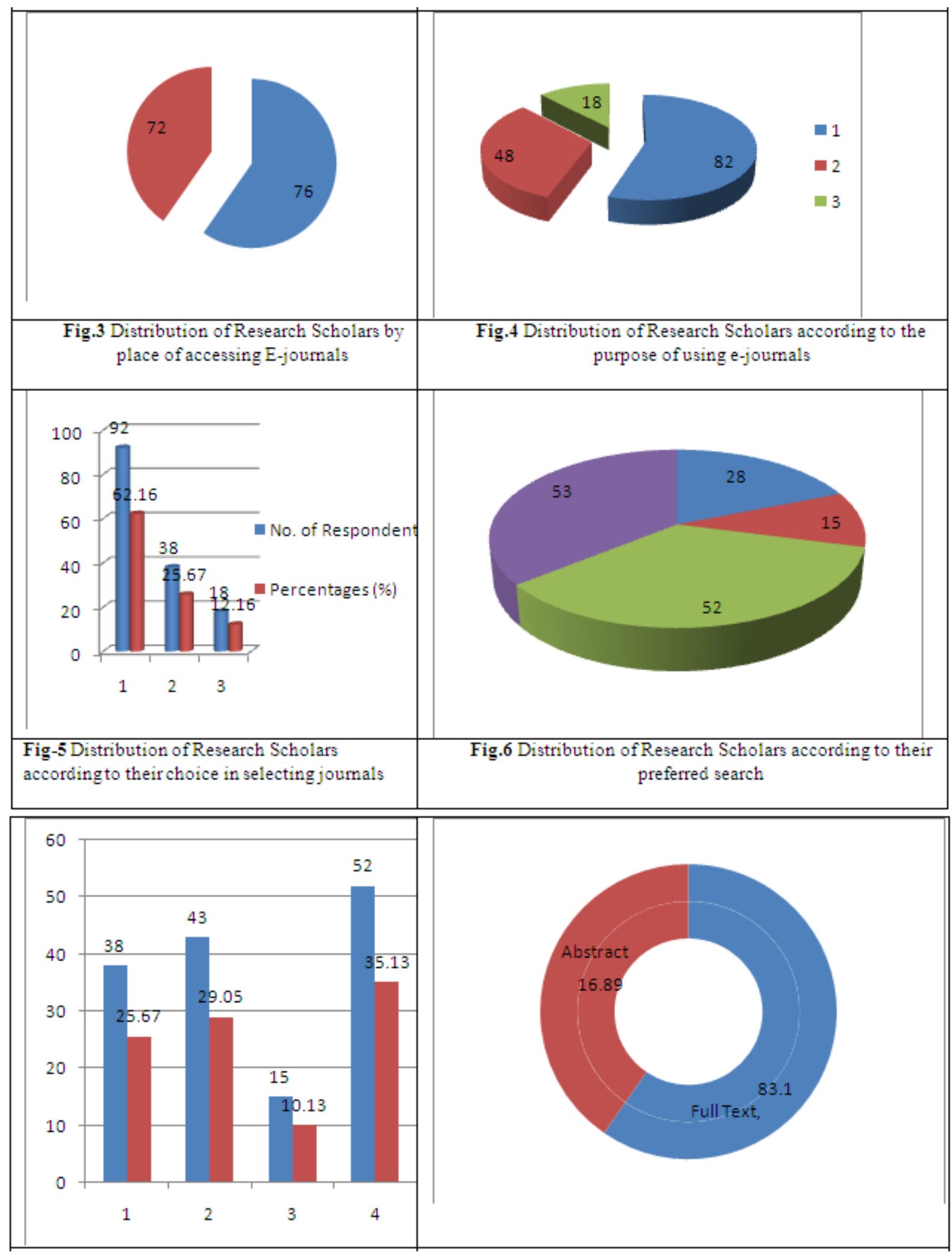


Use of Electronic Journals through Ugc-Infonet Consortium by the Research Scholars of ....

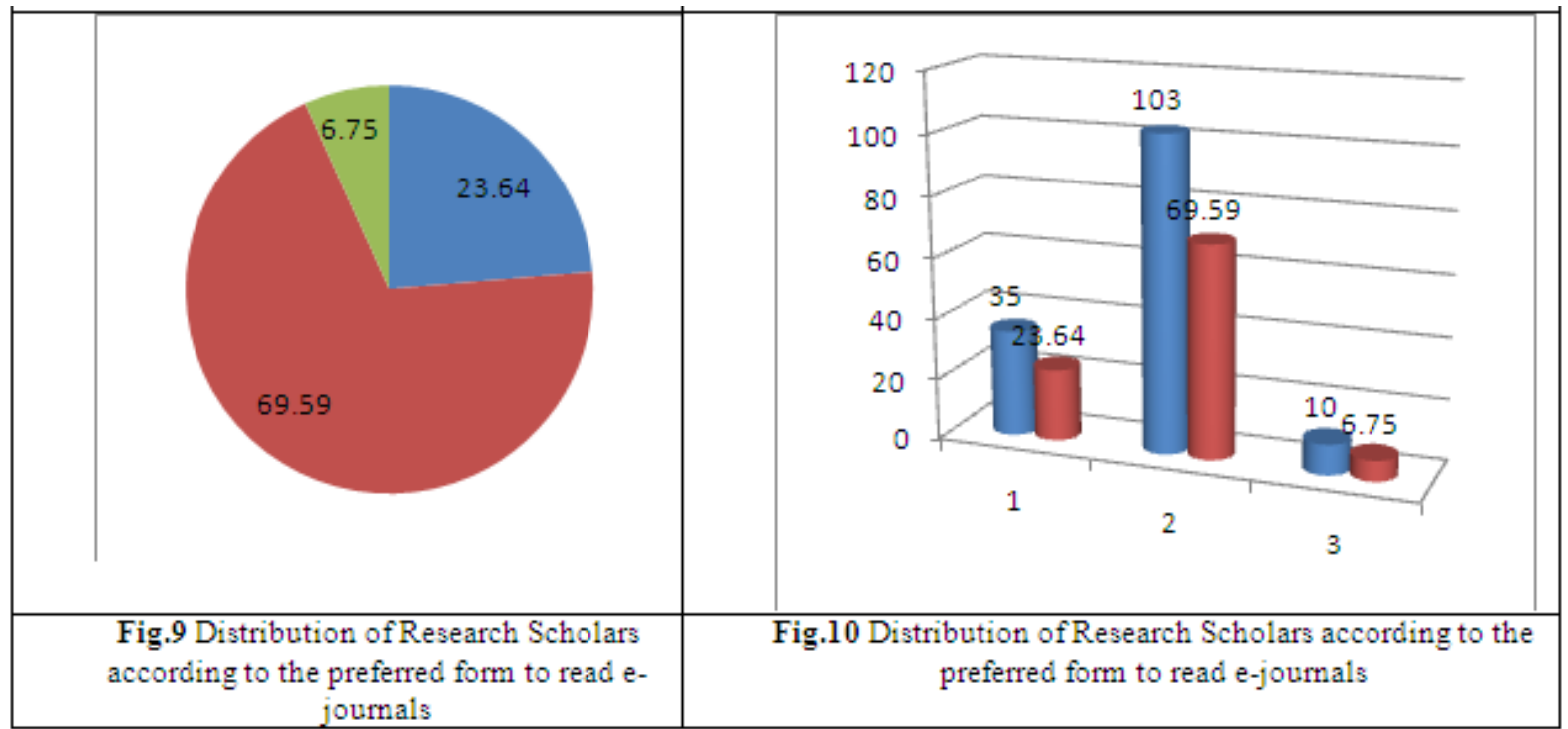

Table.1 Distribution of Research Scholars by frequency of visits to the University Library

\begin{tabular}{|l|l|l|l|}
\hline SI.No. & Frequency of Visits to the University Library & No. of Respondents & Percentages (\%) \\
\hline 1 & Daily & 64 & 43.24 \\
\hline 2 & Once in a week & 42 & 28.37 \\
\hline 3 & Once in a fortnight & 21 & 14.18 \\
\hline 4 & Once in a month & 13 & 8.78 \\
\hline 5 & Occasionally & 8 & 5.41 \\
\hline
\end{tabular}

Table .2 Distribution of Research Scholars by awareness on UGC-Infonet Consortium

\begin{tabular}{|c|c|cc|c|}
\hline Sl.No. & Awareness on UGC-INFONET & No. of Respondents & Percentages (\%) \\
\hline 1 & Yes & 148 & 100 \\
\hline 2 & No & \multicolumn{2}{c|}{} \\
\hline
\end{tabular}

Table .3 Distribution of Research Scholars by sources through which Consortium known

\begin{tabular}{|l|c|l|l|}
\hline SI.No. & Sources through which UGC-INFONET known & No. of Respondents & Percentages (\%) \\
\hline 1 & Library Staff & 82 & 55.41 \\
\hline 2 & Teachers & 21 & 14.18 \\
\hline 3 & Friends & 32 & 21.62 \\
\hline 4 & Self taught & 13 & 8.78 \\
\hline
\end{tabular}

Table .4 Distribution of Research Scholars by place of accessing E-journals

\begin{tabular}{|l|l|l|l|}
\hline Sl.No. & Place of accessing E-journals & No. of Respondents & Percentages (\%) \\
\hline 1 & Library & 72 & 48.64 \\
\hline 2 & Department & 76 & 51.36 \\
\hline
\end{tabular}

Table .5 Distribution of Research Scholars according to the purpose of using e-journals

\begin{tabular}{|l|l|c|c|}
\hline SI.No. & Purpose & No. of Respondents & Percentages (\%) \\
\hline 1 & Study/Research & 82 & 55.41 \\
\hline 2 & Publish articles & 48 & 32.43 \\
\hline 3 & Keep up to date in the subject area & 18 & 12.16 \\
\hline
\end{tabular}

Table. 6 Distribution of Research Scholars according to their choice in selecting journals

\begin{tabular}{|l|l|c|c|}
\hline Sl.No. & Type of referred journals & No. of Respondents & Percentages (\%) \\
\hline 1 & Peer reviewed Journals & 92 & 62.16 \\
\hline 2 & Professional Journals & 38 & 25.67 \\
\hline 3 & Society Publications & 18 & 12.16 \\
\hline
\end{tabular}

Table - 7 Distribution of Research Scholars according to their preferred search

\begin{tabular}{|l|l|c|c|}
\hline Sl.No. & Preferred Search & No. of Respondents & Percentages (\%) \\
\hline 1 & Quick Search & 28 & 18.91 \\
\hline 2 & Advanced Search & 15 & 10.13 \\
\hline 3 & Browse Journals & 52 & 35.13 \\
\hline 4 & My Journals & 53 & 35.81 \\
\hline
\end{tabular}


Use of Electronic Journals through Ugc-Infonet Consortium by the Research Scholars of ....

Table .8 Distribution of Research Scholars according to search method

\begin{tabular}{|l|l|c|c|}
\hline Sl.No. & Search Method & No. of Respondents & Percentages (\%) \\
\hline 1 & Author & 38 & 25.67 \\
\hline 2 & Title & 43 & 29.05 \\
\hline 3 & Subject & 15 & 10.13 \\
\hline 4 & Keywords & 52 & 35.13 \\
\hline
\end{tabular}

Table .9 Distribution of Research Scholars according to the preferred form of e-journal

\begin{tabular}{|l|l|c|c|}
\hline Sl.No. & Preferred form of e-journal & No. of Respondents & Percentages (\%) \\
\hline 1 & Abstract & 25 & 16.89 \\
\hline 2 & Full Text & 123 & 83.10 \\
\hline
\end{tabular}

Table.10 Distribution of Research Scholars according to the preferred form to read e-journals

\begin{tabular}{|l|l|c|c|}
\hline Sl.No. & Preferred form to read e-journals & No. of Respondents & Percentages (\%) \\
\hline 1 & Read articles online & 35 & 23.64 \\
\hline 2 & $\begin{array}{l}\text { Save articles in a separate folder for further } \\
\text { reference }\end{array}$ & 103 & 69.59 \\
\hline 3 & Printout form & 10 & 6.75 \\
\hline
\end{tabular}

Table.11 Distribution of Research Scholars according to the Impact of UGC-Infonet journal on study/research

\begin{tabular}{|l|c|c|c|}
\hline Sl.No. & $\begin{array}{l}\text { Impact of UGC-Infonet Journals on } \\
\text { Study/Research }\end{array}$ & No. of Respondents & Percentages (\%) \\
\hline 1 & Yes & 148 & 100 \\
\hline 2 & No & - & - \\
\hline
\end{tabular}

Table.12 Distribution of Research Scholars according to the satisfaction with existing Internet facility

\begin{tabular}{|l|c|c|c|}
\hline Sl.No. & Satisfaction with existing Internet facility & No. of Respondents & Percentages (\%) \\
\hline 1 & Yes & 98 & 66.21 \\
\hline 2 & No & 50 & 33.78 \\
\hline
\end{tabular}

Table.13 Distribution of Research Scholars according to the opinion about Information content in E-journals

\begin{tabular}{|l|l|c|c|}
\hline SI.No. & $\begin{array}{l}\text { Opinion about Information content in E- } \\
\text { journals when compared to print versions }\end{array}$ & No. of Respondents & Percentages (\%) \\
\hline 1 & Better than print versions & 94 & 63.51 \\
\hline 2 & Same as that of versions & 12 & 8.10 \\
\hline 3 & Not better than print versions & 4 & 2.71 \\
\hline 4 & Not sure & 38 & 25.67 \\
\hline
\end{tabular}

Table.14 Distribution of Research Scholars according to the problems while accessing e-journals

\begin{tabular}{|l|l|c|c|}
\hline SI.No. & Problems faced by respondents while accessing e-journals & No. of Respondents & Percentages (\%) \\
\hline 1 & Lack of availability of personal computers and bandwidth & 25 & 16.89 \\
\hline 2 & Unfamiliarity with the search methods & 113 & 76.35 \\
\hline 3 & Information is not relevant to the subject & 7 & 4.72 \\
\hline 4 & Lack of support from the library staff & 3 & 2.02 \\
\hline
\end{tabular}

Table.15 Distribution of Research Scholars according to the need for orientation/training programme

\begin{tabular}{|l|c|c|c|}
\hline Sl.No. & Need for orientation/Training programme & No. of Respondents & Percentages (\%) \\
\hline 1 & Yes & 102 & 68.91 \\
\hline 2 & No & 46 & 31.09 \\
\hline
\end{tabular}

Table.16 Distribution of Research Scholars on opinion about UGC-Infonet Consortium is boon for researchers

\begin{tabular}{|c|c|c|c|}
\hline Sl.No. & Opinion about UGC-Infonet Consortium & No. of Respondents & Percentages (\%) \\
\hline 1 & Yes & 125 & 84.46 \\
\hline 2 & No & 23 & 15.54 \\
\hline
\end{tabular}

\section{Conclusions}

1. More number of users were visiting the library daily.

2. All the users were aware of the UGC-Infonet Consortium

3. More number of respondents knew the consortium through library staff

4. Maximum number of users were accessing e-journals from their respective departments

5. A good number of users were accessing the e-journals for their study/research.

6. Maximum number of users were referring peer reviewed journals

7. More number of users were using My Journals option. 8. Maximum number of users were accessing ejournals through the keyword search method and they were accessing full text of the articles

9. Maximum number of respondents stored articles in a separate folder for further reference 
10. All the respondents agreed that e-journals had a positive impact on their study/research

11. Maximum numbers of users were satisfied with the Internet facility

12. A good number of users opined that information content on e-journals was better than print versions.

13. Maximum number of users felt that unfamiliarity of the search methods was itself a problem

14. Maximum number of users are felt the need for training on how to use e-journals.

15. Maximum number of users opined that UGC-Infonet consortium was a boon for them.

16. $113(76.35 \%)$ respondents found some problems with the unfamiliarity regarding the search methods and about $102(68.91 \%)$ respondents stated that the training programme was required. The authorities of Sri Venkateswara University Library needed to take necessary steps regarding the training programme.

Recognizing the significance of consortia in the networked soceity, many academic institutions and libraries in India have setup consortia for E-resource sharing. UGC-Infonet facilitating access to select journals to all researchers. The present study reveals that UGC-Infonet has a positive impact on users' study/research.

\section{References:}

[1]. Ahmad, N., Basha,I., and Fatima, N. (2012).Use of UGC-Infonet Consortia by the Research Scholars at University of Delhi: A Survey.Library Philosophy and practice. Retrieved from http://unllib.unl.edu/LPP/on $27^{\text {th }} \mathrm{July}, 2014$.

[2]. R.K. Bhatt, (2010) . Use of UGC-Infonet Digital Library Consortium resources by research scholars and faculty members of the University of Delhi in History and Political Science: A study. Library Management, Vol. 31, 4/5, pp.319 - 343

[3]. Vishala,K., B and Bhandi, M.K.(2005). Access to E-journals in Library and Information Science Area through UGC-INFONET Project,SRELS Journal of Information Management, 42 (4),pp465-482.

[4]. Madhusudhan, M. (2008) "Use of UGC-Infonet e-journals by research scholars and students of the University of Delhi, Delhi: A study", Library Hi Tech, Vol. 26, 3, pp.369-386

[5]. Baskaran, C and Kishore Kumar, S. (2013). Scholarly Journals Access through UGC-INFONET among the faculty members in Alagappa University, Karaikudi, Tamilnadu. SRELS Journal of Information Management,50,2, pp201-207.

[6]. Nagesh Lakshman, D and Neela, J.D.(2013). Usage study of UGC-INFONET E-resources at University of Pune, DESIDOC Journal of Library and Inforamtion Technology,33,5,pp385-393

[7]. Mukherjee, B and Prashant Kumar. (2010).Use of UGC-INFOENT E-Journals by research scholars of the Banaras Hindu University Varanasi, A Case Study,Annals of Library and Information Studies, 57 (4), pp339-347.

[8]. http://www.inflibnet.ac.in/econ/jccc.php. Retrieved on $24^{\text {th }} \mathrm{July}, 2014$.

[9]. http://lib.svuniversity.ac.in/svu/about us.htm. Retrieved on 24th July, 2014 